\title{
Current status, enablers \& barriers of implementing cellular manufacturing system in Indian industries
}

\author{
Amit R. Dixit • Manish Gupta
}

Received: 29 June 2013/ Accepted: 28 November 2013/Published online: 12 December 2013

(C) Shanghai University and Springer-Verlag Berlin Heidelberg 2013

\begin{abstract}
The cellular manufacturing $(\mathrm{CM})$ has been proved as a well-known manufacturing strategy that helps to improve manufacturing efficiency and productivity by utilizing the philosophy of group technology. Large number of papers has been published in the area of design issues of CM system. Unfortunately, the issues related to acceptability of CM in Indian industries are typically not examined rigorously as technical issues. This paper presents the results of a survey carried out to find the status, enabler and barrier of implementing CM system in Indian industries.
\end{abstract}

Keywords Cellular manufacturing (CM) · Group technology $\cdot$ Advanced manufacturing system $\cdot$ Plant layout

\section{Introduction}

Nowadays, the manufacturers are continuously seeking ways and measures to gain competitive advantages. As competition intensifies, they have to enhance their manufacturing flexibility, quality, and costs. Consequently they have become more and more open to new and innovative ideas that are perpetuated to yield competitive gains.

\footnotetext{
A. R. Dixit ( $₫)$

Department of Mechanical Engineering, Indian School of Mines, Dhanbad, India

e-mail: amitraidixit@gmail.com

M. Gupta

Department of Mechanical Engineering, MNNIT, Allahabad, India

e-mail: mgupta@mnnit.ac.in
}

In recent years, batch manufacturing has been prevalent and dominant because of emerging the era of mass customization of products all over the world. The batch manufacturing has high-level product variety and small manufacturing lot sizes. To compete in global market, it is essential to improve the productivity in small batch manufacturing industries. For this purpose, some innovative methods are needed to reduce the product cost, throughput time and enhance the product quality and flexibility to help to increase market share and profitability. One way to achieve this combination of objectives is to redesign the production system as conceived in the principles of group technology (GT). GT aims at searching for similarity within the production system and product structure, and using this similarity to simplify the production. As a result, cellular manufacturing (CM), an application of GT, has emerged as a promising alternative manufacturing system. Some firms have introduced CM as a consequence of the application of GT to their production system [1, 2].

GT was originally emerged as a single-machine concept as created by Mitrofanov in Russia [3]. A number of similar parts were grouped and loaded successively on a machine in order to maximize the use of a single setup, or to reduce the setup time, necessary to produce the group of parts. Thus, machine utilization (i.e., actual operating times) could be increased above the $40 \%$ level accepted as normal in a functional layout-based system [4]. This grouping allows the use of high-output machines, which were previously uneconomical due to large setup times in a job shop layout. This concept was further extended by collecting parts with similar machining equipments and processing them completely on a group of machines (cell). The concept of GT has also been extended into the domain of design and process planning. Parts having some of the similarities in design features are classified in groups. This 
facilitates in developing designs for future parts, and making part substitutions. On the other hand, the variant method of process planning, i.e., developing process plans from existing ones which are similar, can be extensively used. Therefore, from the manufacturing point of view, GT is a management strategy that aims to group together parts that require similar operations and machines corresponding to these operations, which in turn results in part families and machine cells. A large number of parts (machines) can be grouped into a smaller number of part families (machine cells). This type of manufacturing system is known as CM system (CMS).

$\mathrm{CM}$ has been proven to be very successful when implemented properly. Prior studies [1, 5-7] have shown the following dramatic improvements: throughput time $(5 \%-90 \%)$, work-in-process inventory $(8 \%-80 \%)$, material handling (10\%-83\%), job satisfaction (15\%-50\%), fixtures (10\%-85\%), setup time $(2 \%-95 \%)$, space needed $(1 \%-$ $85 \%)$, quality (5\%-90\%), finished goods (70\%-75\%).

The above advantages essentially lower manufacturing cost and produce a higher quality product. This is what makes CM so attractive. CM is intended for medium variety and medium volume production environments. However, manufacturing cells can be used whenever short sequences of processing steps are found with sufficient demand volume to justify dedicated equipment [8].

\section{Literature review}

In the last three decades, a large number of research papers and technical reports have been published in the field of $\mathrm{CM}$. Most of them have focused on providing the amicable solution methodology for cell formation problem. As a result, a wide variety of methods for addressing the cell formation problem have been developed. These range from simple visual methods to complex mathematical models. Reviews of existing $\mathrm{CM}$ literature can be found in numerous published papers [9-16].

Majority of research papers in the field of $\mathrm{CM}$ are related to the theoretical aspects of designing the $\mathrm{CM}$ systems. The issues related to the (i) practical implementation of theoretical techniques, (ii) issues related to implementations, (iii) the implementation status of CM and their effectiveness, (iv) the relative importance of various enablers, barriers, outputs, and benefits and also their effect on CM effectiveness, (v) the effect of those anablers and barriers along with the stage of development on the benefits and outputs, and (vi) the correlation among the various variables of the study, are not addressed well in the literatures.

The inside knowledge of implementation issues of CM revealed from the case studies of the individual firms. Very few studies have surveyed large groups of companies. Few authors [1, 2, 17] have conducted mail based survey studies in American and Japanese industries.

Earlier, few large scale studies of companies which use CM have been conducted [2, 17]. Hyer [18] surveyed American adopters of the GT concept. Levulis [19] studied more than 20 US users of GT using unstructured interviews. Magjuka and Schmenner [20] used data from a large global data base of manufacturing firms to draw conclusions about firms believed to adopters of CM. Burbridge provides limited benefits statistics and implementation experiences for a small number of firms [21]. Dale and Willey collected extensive data from 28 firms with cells [22, 23]. Harvey [24] conducted a study of 11 plants using a combined case study and survey approach. This study, focusing mostly on implementation and industrial relation aspects, did not collect performance data. Dale [22] presented the extensive studies of cell advantages by using the data from 35 industries to determine regression models through which a companys future performance under CM could be predicted. Burbridge carried out these studies for industries located in Britain. A large global data base has been used by Magjuka and Schmenner [20] to draw conclusions about firms believed to be adopters of CM [2].

Wemmerlov and Johnson [2] conducted a detailed survey of plants involved with CM. A target population of highprobability user received mail questionnaires designed to collect responses related to characteristics of industry cells and the firms that have implemented them. Forty six plants supplied detailed data on 126 of their cells, including reasons for establishing them, types of operations performed in the cells, problem faced and feedback received during the implementation, and achieved performance improvements. The study reveals that manufacturing cells, which may house a large variety and many combinations of processes, can provide substantial benefits with respect to strategic dimensions such as manufacturing lead time, customer response time and quality. Authors also support the notion that implementing CM is not merely an issue that involves and affects the organizational and human aspects of the manufacturing firms.

Olorumnniwo [25] analysed a part of the data collected in a survey of US firms that operate manufacturing cells. The author identified two underlying dimensions (delivery response and quality cost) that explain the relationships among the performance measures commonly used to assess the relative magnitude of success of CM implementation. Scrap-rework and throughput time were identified as appropriate surrogate measures respectively for delivery response and quality cost, indicating that those two variables might suffice to monitor success of CM implementation.

Chandra and Sastry [26] conducted a survey to study the competitiveness of Indian manufacturing sector. The 
survey report conceptualized these findings in terms of priorities of Indian manufacturing firms, the programmes that they undertake to reach their objectives, and the outcome or the performance of these firms. Some international comparisons based on a similar study done in the USA were also presented. The report highlighted the role of innovation and supply chain management, as a part of any robust manufacturing strategy, in developing world class operations.

Farooquie and Mohapatra [27] attempted to study the experiences of a few selected Indian manufacturing organizations, operating in and around New Delhi region, regarding the implementation and adaptability of popular Japanese techniques (kaizen, quality circles, total productive maintenance, and just-in-time, etc.) and practices. A structured questionnaire based approach was used for data collection. The results were obtained using descriptive analysis, hypothesis testing, and coefficient of correlation.

Natesan et al [28] used analytical hierarchy process (AHP) method to justify the investment with respect to the benefits with the alternatives of existing traditional manufacturing system the company has and the CM. Silvio et al [29] presented report based on an industrial visit for reconfiguration of a production system into $\mathrm{CM}$ based system. This study also compares the reconfigured system with the previous system on different parameters namely work flow, reliability, etc.

Askin et al [30] surveyed the research papers related to development in the area of CM. The author reported that DATA management and organization practices/limitation are vital factors and should be considered while designing the CMS. The other important issues is related to human factor.

\section{Survey methodology and aspects}

The questionnaire, used in the survey, was designed on the basis of the existing literature and the conclusion obtained from the previously conducted cases studies [1, 22]. Most of these questions were framed on a 5-point Likert scale. A total of 180 questionnaires together with the covering letter explaining the purpose of the study and the confidential letter, were mailed to different organisations throughout the country. These industries ranged from public sector, private sector and government organisations. These included industries involved in the manufacturing of automobile, defense aircrafts, electrical equipment, electronic and telecommunications equipments, textile, chemicals and fertilizers, etc. The questionnaire was addressed to the high, middle and lower level management personnel. The questionnaire sought information on demographic profile of the organisations, status of CM system and its enablers, the present advanced manufacturing practices used in
Table 1 Various sectors participated in survey

\begin{tabular}{llllc}
\hline & $\begin{array}{l}\text { Times of the } \\
\text { particular option } \\
\text { opted in the total } \\
\text { responses }\end{array}$ & $\begin{array}{l}\text { Percent/ } \\
\text { Valid } \\
\text { percent/ }\end{array}$ & $\begin{array}{l}\text { Cumulative } \\
\text { percent/\% }\end{array}$ \\
\hline $\begin{array}{c}\text { Basic metals } \\
\text { and } \\
\text { fabricated } \\
\text { metal } \\
\text { products }\end{array}$ & 2 & 6.1 & 6.1 & 6.1 \\
$\begin{array}{c}\text { Electronic } \\
\text { equipment } \\
\text { and } \\
\text { apparatus }\end{array}$ & 8 & & & \\
$\begin{array}{c}\text { Textile and } \\
\text { leather } \\
\text { products }\end{array}$ & 2 & 24.2 & 24.2 & 30.3 \\
$\begin{array}{c}\text { Machinery/ } \\
\text { machine } \\
\text { tools }\end{array}$ & 4 & & & \\
$\begin{array}{c}\text { Transport } \\
\text { devices }\end{array}$ & 1 & 6.1 & 6.1 & 36.4 \\
$\begin{array}{c}\text { Paper and } \\
\text { paper } \\
\text { products }\end{array}$ & 1 & 12.1 & 12.1 & 48.5 \\
$\begin{array}{l}\text { Automotive } \\
\text { Aerospace }\end{array}$ & 6 & & & \\
\hline
\end{tabular}

Indian industries and barriers faced by the industry to implement CMS in the organization.

In order to establish the validity of the contents in the questionnaire, a pilot study was conducted with the help of academicians, consultants and the executives working in the organizations. The questionnaire was modified by incorporating some questions suggested in pilot study, removing the irrelevant question and modifying few existing questions to bring in more clarity in the questionnaire. Finally, survey instrument was send through post, email, personally to different organisations. The questionnaire was also uploaded on Google cloud [31] for quick responses. Approximately 180 questionnaires were sent to executives/senior managers and mangers. 18 questionnaires returned undelivered and 27 organisations refused to participate in the survey as they were not permitted to share the information with others. A total of 36 responses were collected. However, out of the 36 responses received, 3 responses were incomplete and were excluded from the analysis. Thus 33 complete responses were collected, which gives an effective response rate of $18.3 \%$. The response rate is less compared to some of the surveys conducted by the researchers in this area. The problem of low response rate is more serious in Indian manufacturing companies as these companies are generally reluctant to share confidential data [32]. The limitation imposed by low response rates were closely reported by Gascoigne and 
Table 2 The (financial) annual turnover of the firms (in millions)

\begin{tabular}{llcc}
\hline & $\begin{array}{l}\text { Times of the } \\
\text { particular option } \\
\text { opted in the total } \\
\text { responses }\end{array}$ & Percent/\% & Valid percent/\% \\
\hline Less than 0.50 & 3 & 9.1 & 9.4 \\
$0.50-5$ & 6 & 18.2 & 18.8 \\
$5-50$ & 5 & 15.2 & 15.6 \\
More than 50 & 15 & 45.5 & 46.9 \\
Total & 32 & 97.0 & 100.0 \\
\hline
\end{tabular}

Table 3 Turnover growth over the past five years in different sectors

\begin{tabular}{lccllc}
\hline & $0-10 \%$ & $\begin{array}{l}11 \%- \\
25 \%\end{array}$ & $\begin{array}{l}\text { More } \\
\text { than } \\
25 \%\end{array}$ & $\begin{array}{l}\text { No } \\
\text { change }\end{array}$ & Total \\
\hline $\begin{array}{l}\text { Basic metals and } \\
\text { fabricated metal } \\
\text { products }\end{array}$ & 0 & 1 & 1 & 0 & 2 \\
$\begin{array}{l}\text { Electronic equipment } \\
\text { and apparatus }\end{array}$ & 4 & 2 & 1 & 1 & 8 \\
$\begin{array}{l}\text { Textile and leather } \\
\text { products }\end{array}$ & 2 & 0 & 0 & 0 & 2 \\
$\begin{array}{l}\text { Machinery/machine } \\
\text { tools }\end{array}$ & 1 & 1 & 2 & 0 & 4 \\
$\begin{array}{l}\text { Transport devices } \\
\begin{array}{l}\text { Paper and paper } \\
\text { products }\end{array}\end{array}$ & 0 & 1 & 0 & 0 & 1 \\
$\begin{array}{l}\text { Automotive } \\
\text { Aerospace }\end{array}$ & 2 & 4 & 0 & 0 & 1 \\
\begin{tabular}{l} 
Total \\
\hline
\end{tabular} & 3 & 3 & 3 & 0 & 9 \\
\end{tabular}

Weston [33]. According to author, their empirical study may provide some fruitful understanding, but it cannot be claimed to represent the UK marketplace due to limited repose rate. Similarly, this survey also throws light on different aspects of CM system in Indian organisations.

\section{Survey analysis}

The 33 firms, participated in the survey process, belong to different sector, as indicated in Table 1 . The main sectors include aerospace $(27.3 \%)$, electronic equipment and apparatus $(24.2 \%)$, automotive $(18.3 \%)$ and machinery and machine tool $(12.1 \%)$. The annual financial turnover of different firms is shown in Table 2. About $46 \%$ of the surveyed companies have annual turnover more than 50 millions. It indicates that they are large scale companies.

Table 3 indicates the growth trend in turnover of these firms for last 5 years. The majority $(93.6 \%)$ of these respondents has claimed the growth in the range of $0-25 \%$.
Table 4 Number of employees in the firm

\begin{tabular}{lllll}
\hline & $\begin{array}{l}\text { Times of the } \\
\text { particular option } \\
\text { opted in the total } \\
\text { responses }\end{array}$ & $\begin{array}{l}\text { Percent/ } \\
\text { Valid } \\
\text { percent/ }\end{array}$ & $\begin{array}{l}\text { Cumulative } \\
\text { percent/\% }\end{array}$ \\
\hline Less than 50 & 4 & 12.1 & 12.1 & 12.1 \\
$50-100$ & 4 & 12.1 & 12.1 & 24.2 \\
$101-500$ & 6 & 18.2 & 18.2 & 42.4 \\
$501-1,000$ & 3 & 9.1 & 9.1 & 51.5 \\
$\begin{array}{l}\text { More than } \\
1,001\end{array}$ & 16 & 48.5 & 48.5 & 100.0 \\
Total & 33 & 100.0 & 100.0 & \\
\hline
\end{tabular}

Table 5 Position in the organization

\begin{tabular}{lllll}
\hline & $\begin{array}{l}\text { Times of the } \\
\text { particular option } \\
\text { opted in the total } \\
\text { responses }\end{array}$ & $\begin{array}{l}\text { Percent/ } \\
\text { Valid } \\
\text { percent/ } \\
\%\end{array}$ & $\begin{array}{l}\text { Cumulative } \\
\text { percent/\% }\end{array}$ \\
\hline $\begin{array}{l}\text { Senior } \\
\text { management } \\
\text { level }\end{array}$ & 9 & 27.3 & 27.3 & 27.3 \\
$\begin{array}{l}\text { Middle } \\
\text { management } \\
\text { level }\end{array}$ & 14 & & & \\
$\begin{array}{l}\text { Junior } \\
\text { management }\end{array}$ & 9 & 42.4 & 42.4 & 69.7 \\
$\quad$ level & & 27.3 & 27.3 & 97.0 \\
$\begin{array}{l}\text { Others } \\
\text { Total }\end{array}$ & 1 & & & \\
\hline
\end{tabular}

Table 6 Number of different production departments

\begin{tabular}{llllr}
\hline & $\begin{array}{l}\text { Times of the } \\
\text { particular option } \\
\text { opted in the total } \\
\text { responses }\end{array}$ & $\begin{array}{l}\text { Percent/ } \\
\%\end{array}$ & $\begin{array}{l}\text { Valid } \\
\text { percent// }\end{array}$ & $\begin{array}{l}\text { Cumulative } \\
\text { percent/\% }\end{array}$ \\
\hline 0 & 1 & 3.0 & 3.4 & 3.4 \\
1 & 3 & 9.1 & 10.3 & 13.8 \\
$2-3$ & 3 & 9.1 & 10.3 & 24.1 \\
$4-6$ & 9 & 27.3 & 31.0 & 55.2 \\
More than & 13 & 39.4 & 44.8 & 100.0 \\
10 & & & & \\
Missing & 4 & 12.1 & & \\
system & & & & \\
Total & 33 & 100.0 & & \\
\hline
\end{tabular}

This mainly includes aerospace, manufacturing and automotive sector. The sector-wise growth is shown in Table 3 . The revealed trend is also supported by the report published by ACME and CII report.

$12.1 \%$ respondent organisations have less than 50 employees and another $12.1 \%$ organisations have about 
Table 7 Cronbach's coefficient (alpha) value for different items

\begin{tabular}{llll}
\hline Items & $\begin{array}{l}\text { Cronbach's } \\
\text { alpha }\end{array}$ & $\begin{array}{l}\text { Cronbach's alpha } \\
\text { based on } \\
\text { standardized } \\
\text { items }\end{array}$ & $\begin{array}{l}\text { No. of } \\
\text { valid } \\
\text { cases }\end{array}$ \\
\hline $\begin{array}{l}\text { Benefits of CMS } \\
\begin{array}{l}\text { Current status of } \\
\text { advanced } \\
\text { manufacturing } \\
\text { technology (AMT) in } \\
\text { industry }\end{array}\end{array}$ & 0.974 & 0.976 & 20 \\
$\begin{array}{l}\text { Barriers of implantation } \\
\text { of CMS }\end{array}$ & 0.947 & 0.944 & 24 \\
\hline
\end{tabular}

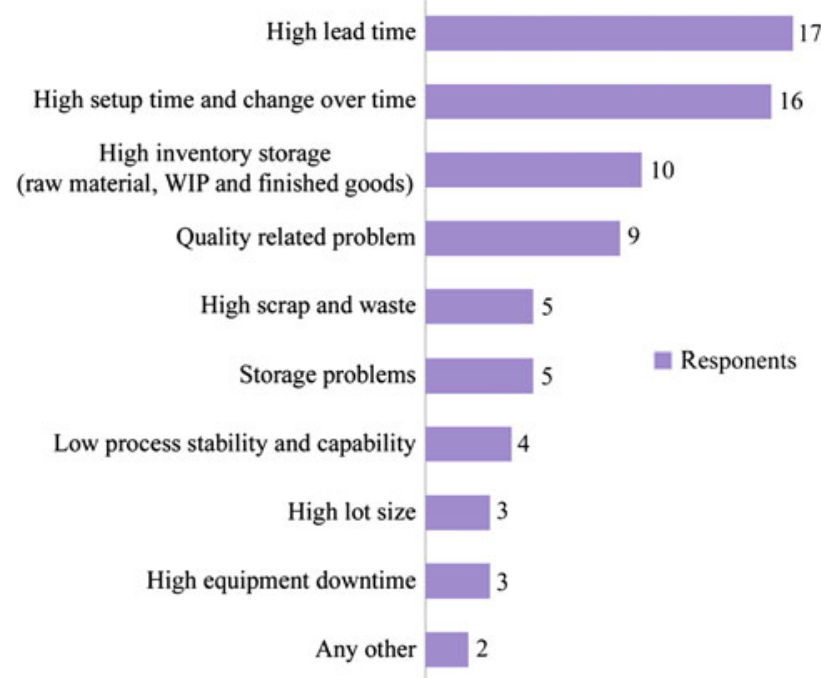

Fig. 1 Production related problems faced by the respondents

51-00 employees, $18.2 \%$ organisations have about 101-500 employees, 9.1\% organisations have about 501-1,000 employees and 48.5\% organisations have reported to have more than 1,000 employees (see Table 4).

The questionnaires have been filled by the senior management level (27.3\%), middle management level (42.4\%) and junior management level (27.3\%) (see Table 5). The surveyed companies have more than one production departments within their firm. As indicated in Table 6, about $44.8 \%$ respondents operates more than 10 production departments, $31 \%$ have 4-6 production departments, $10.3 \%$ have $2-3$ production and $10.3 \%$ has only one production department.

Reliability analysis has been carried out to check whether instrument is reliable and valid. The analysis was performed for all such questions where the number of variables exceeded seven. Cronbach's coefficient has been calculated (see Table 7) to find the internal consistency, based on the average inter-item correlation. Chronbach's
Table 8 Dominant manufacturing layout in the company

\begin{tabular}{llllll}
\hline & & \multicolumn{3}{l}{$\begin{array}{l}\text { Group or cellular } \\
\text { layout }\end{array}$} \\
\cline { 2 - 6 } & & No & Yes & Total \\
\hline Process layout (i.e., a job shop) & No & 17 & 4 & 21 \\
Fixed position layout (i.e., project layout & Yes & 10 & 0 & 10 \\
the product stays in place) & No & 20 & 3 & 23 \\
Product layout (i.e., a flow shop) & Yes & 7 & 1 & 8 \\
& No & 14 & 1 & 15 \\
& Yes & 13 & 3 & 16 \\
\hline
\end{tabular}

Table 9 Presence cellular layout in different sectors

\begin{tabular}{llll}
\hline The sector in which firm operates & \multicolumn{3}{l}{$\begin{array}{l}\text { Group or cellular } \\
\text { layout }\end{array}$} \\
\cline { 2 - 4 } & No & Yes & Total \\
\hline Basic metals and fabricated metal products & 2 & 0 & 2 \\
Electronic equipment and apparatus & 8 & 0 & 8 \\
Textile and leather products & 1 & 0 & 1 \\
Machinery/machine tools & 3 & 1 & 4 \\
Transport devices & 0 & 1 & 1 \\
Paper and paper products & 1 & 0 & 1 \\
Automotive & 3 & 2 & 5 \\
Aerospace & 9 & 0 & 9 \\
\hline
\end{tabular}

alpha value for each such questions have found more than 0.5 , which is considered sufficient for exploratory work.

\section{Production related problems}

In order to understand the production related problem in the Indian industry, the respondents were asked to indicate the different problems faced in production in their respective firms. The major problems related to the production are the high lead time (52\%), high setup time and change over time (48\%) and high inventory storage (30\%). It is also worth to note that they rated the high lead time as a major problem in their present production plant (see Fig. 1) but they were not sure about the lead time of the whole firm.

\section{Status of CM layouts in Indian industries}

In order to know the dominant type of manufacturing layout in the surveyed firms, the respondents were asked to select the layout options (process type layout, product type layout, fixed position layout and group or cellular layout). In case of hybrid type layout, the respondents were asked to 


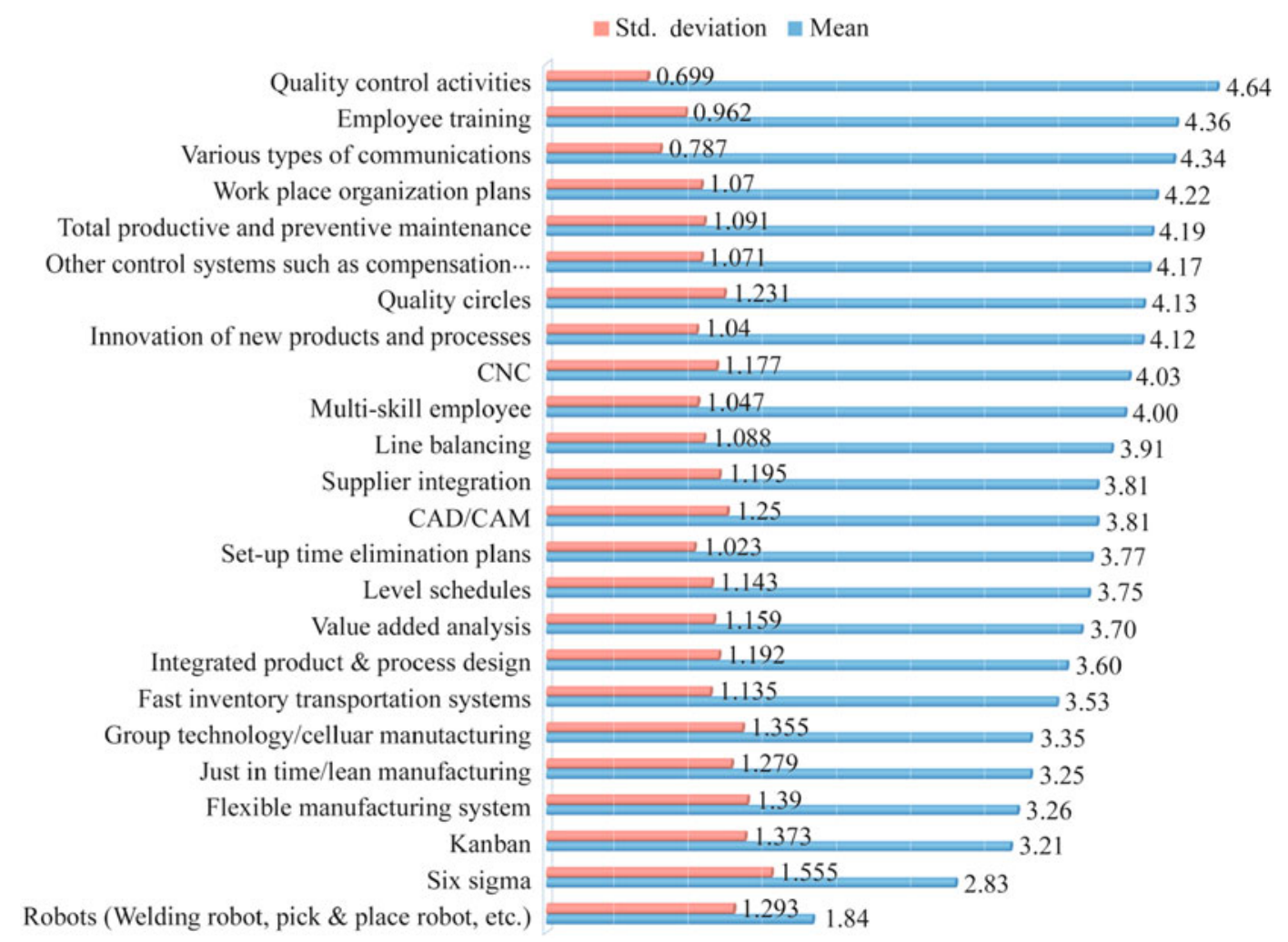

Fig. 2 Status of advanced manufacturing system in Indian industry

select more than one type of layout (see Table 8). The product type layout or flow shop was found in 13 companies, however, among these, 3 companies were using both product layout and cellular layout. Fixed position layout or project layout was also found to be dominant type layout in 7 companies and only one company was using both fixed position and cellular layout. Process layout or job shop was the dominant layout in 10 companies but none of these companies were using the cellular layout. Moreover, the survey data reveled that only $14.8 \%$ of the companies were using group or cellular layout.

It is evident from the survey (see Table 9) that cellular layout exist in more potential sectors like machinery/ machine tool, transport devices and automotive firm. These sectors are found to be fast growing sectors in Indian industries. India is one of the fastest growing economies in the world. This estimate average GDP growth of Indian is around $7.6 \%$ for 2011-2012 (ACMA annual report 2012). The share of these sectors is also phenomenal. However, these sectors are also facing immense pressure either locally or globally encourage industries to become more responsive and agile. The industries of developing countries face many uncertainties when competing in global markets [34].

The manufacturers operation in these sectors are more open to adopt the latest manufacturing technologies and practices. Twenty four critical advanced manufacturing technologies (AMTs) and support activities were identified from different literatures $[35,36]$ and participating industries were asked to indicate to what extent these technologies were applied in their firms. They were asked to rate the implementation on five point likert scale (never used, occasionally used, reasonably used, usually used and always used). The rank of AMT was identified based on the mean score. These technologies along with the mean and standard deviation scores are indicated in Fig. 2.

The quality control activities were ranked highest $($ mean $=4.64$ and standard deviation $(\mathrm{SD})=0.699)$ and application of robot was ranked lowest. GT application was ranked low (rank 20) with mean 3.35 and SD 1.355. This trend was also supported by other survey based findings where CM was rated very low. One of the reasons could be that to evolve to a pull inventory system, manufacturing needs to be reconfigured through cells. The implementation of such system would involve substantial rearrangement of production facility which leads to demand more managerial effort [37].

However, the top 10 advanced manufacturing practices shown in Fig. 2 are related to the managerial aspect and therefore not much investment is required. The companies are still giving comparatively less importance to CAD/ CAM, Just in Time, lean manufacturing, GT, fast inventory 
transport system. Therefore, industries are reluctant to invest (perhaps caused by higher risk) in the installation of robots, implementing $\mathrm{CM}$ and flexible manufacturing, etc. The robots (mean 1.84) and six sigma (mean 2.83) received the least importance in Indian industries.

Nagabhushana [32] also identified 20 important action programmes adopted by Indian industries. The author asked the respondents to rate the action programmes on a three point scale (no emphasis, normal emphasis and great emphasis) based on resources deployment by the company to the programmes. These action programmes were implemented by the industries as their manufacturing priorities. Their finding indicates that the CM/GT placed in bottom ten program based on their mean scores $($ mean $=1.81, \mathrm{SD}=0.74)$. The Indian industries gave more preferences to operational issues like ISO 9000 certification, TQM, worker training, periodic review, staff awareness about cost, etc., rather than strategic issues like JIT, concurrent engineering, reduction of suppliers, etc. In Indian context, a similar study was also carried by Dangayacha and Deshmukh [37]. Their survey revealed that top ten advanced technology and management system adopted in Indian industries were TQM, management training, customer relations, shop floor automation, workforce involvement, employee empowerment, CAD, SPC, MRP and benchmarking, whereas the least preferred ten activities were robotics, AS/RS, bar coding, AGVs, GT, DNC, FMS, AMHS, recycling, and ABC. It is evident that the Indian industries are giving more importance to operational issues like employee training, quality control activities, work place organizational plans etc., which requires significant structural changes. However, at the same time these companies are not showing interest to invest in technological related advancement.

\section{Enablers of implementation of CMS in Indian industries}

The reasons and their relative importance of the implementation of manufacturing cells are shown in Fig. 3. Multiple enablers have been identified by the organization to justify the establishment of cells and several of these are considered critical. For example, the average respondent viewed is not less than 3.37 of the all enablers (see Fig. 3) as being important (improvement 25\%-49\%) for initiating the process of implementation of manufacturing cell in the industries. It is seen that the most important enablers are to seek improvement in productivity and workers skill flexibility. These two reasons received average scores exceed 4 when rated on a scale from 1(no improvement or unimportant) to 5 (improvement more than $75 \%$ or very

- Average importance

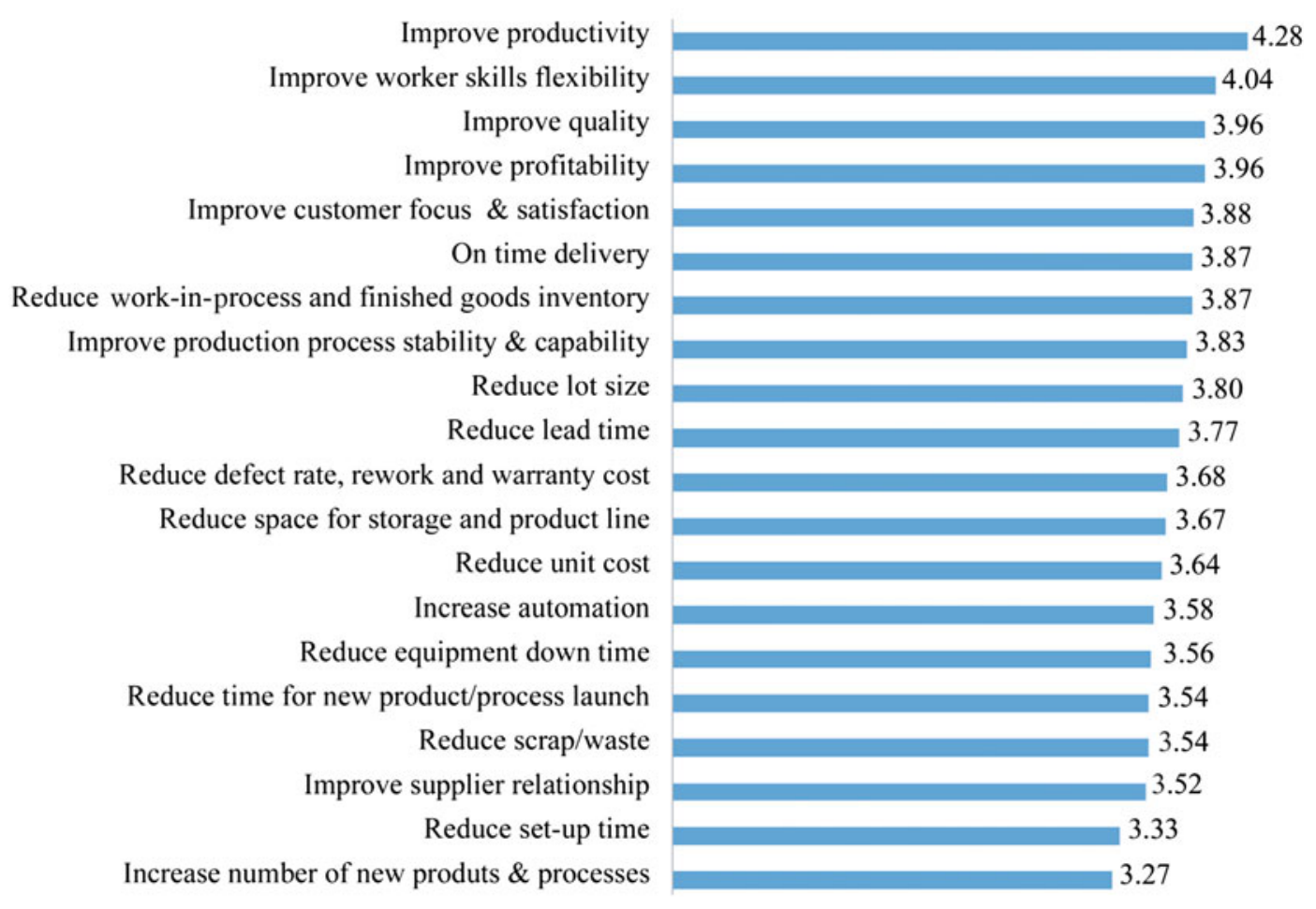

Fig. 3 Enablers of GT/CM layout 
important). With the exception of increasing number of new products $\&$ processes and reducing setup time, they had minimum score. Although the minimum score is 3.27 (important to very important), GT is a technological improvement, and it is from this class of change that companies gain the largest manufacturing productivity increases. Manufacturing productivity has been found to be influenced by three major factors [38]: (i) $15 \%$ can be attributed to improvements in the quality of the work-force. (ii) $25 \%$ is the result of a greater availability of capital. (iii) $60 \%$ is a result of improved production technology. It is this latter major sector of production technology, to which GT contributes.

Wemmerlov and Johnson [1] has identified (i) reduction of throughput time, (ii) work-in-process (WIP) inventory, (iii) part/product quality, (iv) response time to customer orders and (v) move distances/time as the five most important reasons for establishing manufacturing cell. Almost similar results were found in another study conducted by Wemmerlov and Hyer [2]. According to authors, the prominent enablers of manufacturing cells were to reduce WIP inventory, setup time, throughout time and material handling, and to improve output quality.

\section{Barriers of CMS in Indian industries}

The major barrier of implementation of advanced manufacturing technology/system may be classified as structural barrier, human related barrier and technical barrier [39, 40].
The structural barrier is related to organizational infrastructure and justification difficulties, human related barrier indicates the uncertainty and workers resistances and technical barrier is related to the system incompatibility.

In the survey instrument, the respondent were asked to rate the problem encounter (or hope they may encounter) in implementing CM system in their firm (see Table 10). These were asked to rate the problems on three point likert scale (never a barrier, occasionally a barrier and always a barrier). The workers' resistance (mean $=2.15$ and $\mathrm{SD}=0.834$ ) is the most prominent barrier for the implementation of CM system in the Indian firm. Trade union influence is also indentified as the potential obstacles. Adler [41] also identified that in the majority of the cases, issues related to human resource management were found to be prim ary stumbling obstacles in the implementations of new technologies and advanced systems. Bidanda et al [] observed that the conflict management was more of the concern for workers, than to managers. It may 42 be due to the fact that the workers are on the front-line for conflict management. It is important that the managers should be able to sense the conflict and resolve them as soon as possible. If managers overlook conflict, it may create an unhealthy environment. It may also affect the productivity and quality of work of the workers. It also leads to worker job stress in lean production [43]. Resistance to change is also considered to be a factor of human related resistance [30]. The theory of change was developed by Kurt Levin and further described by Ottaway in 1980. Ottaway postulated that any organization operated in a dynamic field of

Table 10 Barriers/obstacles in applying GT/CMS in the firm

\begin{tabular}{|c|c|c|c|c|c|c|}
\hline Barriers/obstacles & $\begin{array}{l}\text { No. of } \\
\text { responses }\end{array}$ & Mean & SD & $\begin{array}{l}\text { Never a } \\
\text { barrier/\% }\end{array}$ & $\begin{array}{l}\text { Occasionally a } \\
\text { barrier/\% }\end{array}$ & $\begin{array}{l}\text { Always a } \\
\text { barrier/\% }\end{array}$ \\
\hline Workers resistance & 33 & 2.15 & 0.834 & 27.3 & 30.3 & 42.4 \\
\hline Influence of trade unions & 32 & 2.09 & 0.893 & 34.4 & 21.9 & 42.8 \\
\hline Lack of training and education in the use of GT techniques & 33 & 2.00 & 0.901 & 39.4 & 21.2 & 39.4 \\
\hline Lack of knowledge about GT principles and techniques & 33 & 1.91 & 0.765 & 33.3 & 42.4 & 24.2 \\
\hline Lack of support from various departments & 33 & 1.82 & 0.683 & 33.3 & 51.5 & 15.2 \\
\hline Factory floor layout & 31 & 1.74 & 0.631 & 65.5 & 34.4 & 0.0 \\
\hline Other external forces & 24 & 1.71 & 0.550 & 33.3 & 62.5 & 4.2 \\
\hline Lack of advanced machinery & 33 & 1.64 & 0.783 & 54.5 & 27.3 & 18.2 \\
\hline Lack of funds & 33 & 1.58 & 0.792 & 60.6 & 21.2 & 18.2 \\
\hline Communication barriers with suppliers & 33 & 1.55 & 0.711 & 57.3 & 34.4 & 6.3 \\
\hline Material transportation problems & 32 & 1.47 & 0.621 & 59.4 & 34.4 & 6.3 \\
\hline Legislations, regulations and policies of government & 30 & 1.47 & 0.629 & 60.0 & 33.3 & 6.7 \\
\hline Managers resistance & 33 & 1.45 & 0.666 & 63.6 & 27.3 & 9.1 \\
\hline Manufacturing process (e.g., job shop, batch, repetitive, flow process) & 33 & 1.39 & 0.609 & 66.7 & 27.3 & 6.1 \\
\hline Working hours & 32 & 1.34 & 0.483 & 65.6 & 34.4 & 0.0 \\
\hline
\end{tabular}

The numbers in italics indicate the response prevailed among the respondents against the identified barriers/obstacles 
Table 11 Strategic priorities adopted by Indian organization

\begin{tabular}{llllll}
\hline Strategic priorities & $\begin{array}{l}\text { Valid/ } \\
\text { N }\end{array}$ & $\begin{array}{l}\text { Missing/ } \\
\mathrm{N}\end{array}$ & Rank & Mean & SD \\
\hline High product reliability & 33 & 0 & 1 & 2.88 & 0.331 \\
High product quality & 33 & 0 & 2 & 2.85 & 0.364 \\
Advanced technology & 32 & 1 & 3 & 2.72 & 0.523 \\
High utilization rates & 31 & 2 & 4 & 2.58 & 0.564 \\
High delivery reliability & 32 & 1 & 5 & 2.53 & 0.567 \\
Quick supply & 32 & 1 & 6 & 2.44 & 0.669 \\
High product-mix & 31 & 2 & 7 & 2.32 & 0.702 \\
$\quad$ flexibility & & & & & \\
High volume flexibility & 30 & 3 & 8 & 2.17 & 0.791 \\
Low prices & 32 & 1 & 9 & 2.16 & 0.628 \\
Short lead-times & 31 & 2 & 10 & 2.10 & 0.651 \\
\hline
\end{tabular}

forces, some pushing for change (higher authority) and other pulling against change (workers). Most of the time, these forces are in equilibrium. The pushing force is for improvement, growth, development, whereas the pull back is for to stable, predictable and acceptable.

In addition to human related obstacle, lack of training and education in the use of GT techniques is also an obstacle of introducing CMS. Training is one of the important considerations of human resource management. Relevant training must be provided on a timely basis. The training must emphasize to develop a workforce that would capable of dealing with working in $\mathrm{CM}$ environment. Therefore, it is important to develop multi-skilled workers who can perform multiple tasks. Support and cooperation of all employees in all levels is essential for the design of effective training programs. Such programs must be developed after the successful assessment of workforce skill.

The knowledge about the GT/CM system is also indicated as potential barrier of CMS implementation in Indian industries. Cantamessa and Turroni [44] observed that gap between academic research and industrial practice is also a significant barrier. Wemmerlov and Hyer [1] hardly found any $\mathrm{CM}$ designed based on academically developed solution technique in any company. One considerable cause for widening research-practice gap is the changing market mechanisms, user perspectives and manufacturing complexity over the last several years [45].

\section{Manufacturing strategies}

Due to global competition and major economic reforms by the government, the Indian manufacturing companies are focusing at the strategic role of manufacturing. This has encouraged Indian companies to give high priority to quality management. The survey shows that to improve the manufacturing competitiveness, Indian industries are giving the highest priority to product reliability and quality. In terms of cost, the result of this study is contradictory to the survey results of Nagabhushana [32], wherein, the cost was ranked the highest (mean $=4.55 \mathrm{SD}=0.64$ ) followed by quality. This shows a paradigm shift, in past $10-12$ years, of the priority of Indian industries, which is focusing more on quality then the cost. The flexibility in both the studies was ranked in the lower half of the list of importance. It seems that the flexibility requires longer time duration to realize the benefits, and the industries preferences are therefore inclined towards those aspect which can provide immediate return on investment.

This study also shows (see Table 11) that most industries is more focusing on product reliability and quality, delivery reliability and advanced technology. However, competitive gain can be obtained through elementary changes in the way manufacturing is organized. It has been found that the Indian industries are giving less importance to flexibility (product-mix and product volume) whereas companies of developing companies like USA, Japan, Korea, UK, etc., are giving the highest priority to flexibility [46].

The Indian industries are giving the highest competitive priority to the quality. It is also evident from the fact that most of the companies are engaged in ISO certification [47]. According to the survey conducted by ISO (source: www.ISO.org), Indian has ranked the eighth in top ten countries for ISO-9001 certification process.

\section{Conclusions}

Most of the surveyed companies are reasonably using advanced manufacturing practices and technology (see Fig. 3) but still these companies are facing problems related to high lead time, high setup and change over time and high inventory storage. It has been argued that the manufacturing companies that adopt AMT without the first reconfiguring the organizational structures and processes are facing such difficulties [48]. Wemmerlov and Hyer [1] identified reduction of WIP inventory, setup time, throughput time, material handling and improvement of output quality as the most common reasons for establishing manufacturing cell in US industries.

Manufacturing cell is a prerequisite for the successful implementation of AMT for automation and integration of manufacturing activities [49, 50]. They have classified AMT into four levels (see Fig. 4). Consideration of technical issues (AMT) alone cannot guarantee that an organization can develop and implement successful CM system [42]. Indian industries may achieve significant improvement by implementing well-prepared strategies. It is 
- Stand alone $\mathrm{CNC} / \mathrm{NC}$ and robot controlled by self-contained computer

- Manufacturing cell and flexible manufacturing system producing variety of tasks to produce a family of parts

- Manufacturing cell are interlinked through network of computerized information like $\mathrm{CAD} / \mathrm{CAM}$, automated storage and retrieval systems

- All the manufacturing activities including marketing of products are integrated through information system to form computerintegrated manufacturing

Fig. 4 Classification of AMT

therefore important to make a noticeable impact in global market, all relevant stakeholders must be considered and involved both in design and implementation process. It is also important for the organizations to study the case studies of the companies where CM has been successfully implemented. Therefore, it is important for Indian industries to initiate the processes of reconfiguration of their facilities and implement CM system in the organization. The companies must also come up with some innovative solutions to overcome the barriers of the implementation of CMS. Few recommendations for reducing workers resistance are given below:

(i) Workers should be involved in the implementation process. The resistance is reduced if workers feel that the project is their own and not imposed from outside. The project should be strongly and unambiguously supported by top official.

(ii) The objectives of the implementation must include issues related to the worker. The implementation project must reduce the present burdens, accord with existing values, offers new interesting experience. In addition, the project should not threaten the autonomy and security.

$\mathrm{CM}$ provides the possibility of improving the quality of working life in two ways, by the use of job enrichment and by the creation of autonomous or self-managing groups [38]. Indian manufacturing sector is very vast and diversified and therefore the findings of any study, based on a small sample may not generalize any specific sector. In this study, an attempt was made to assess the layout strategy issues in Indian industries. This research has certain limitations, which may be consider in future study. The main limitations of this study are:

(i) Sample size of 33, which may be considered as small. This is due to the hesitation of Indian companies to take part in such studies. (ii) The survey may be conducted for the companies with same segments so that the capabilities of particular type of companies may be studied.

(iii) However, irrespective of above mentioned limitations, it is believed that the results and finding of this project shall be useful as suggestive guidelines for those Indian industries that are planning to implement CM systems in order to augment their productivity and improve the competitiveness.

A survey may be conducted in future, targeting the companies where $\mathrm{CM}$ has already been implemented. A performance measurement model may develop and can be applied to $\mathrm{CM}$ enabled manufacturing environments using relevant organisation specific $\mathrm{CM}$ drivers and key performance indicators to optimize system performance.

Acknowledgement This research was funded by the Department of Science \& Technology, Government of India under FAST track scheme for young scientist.

\section{References}

1. Wemmerlov U, Hyer N (1989) Cellular manufacturing in the US industry: a survey of users. Int J Prod Res 27(9):1511-1530

2. Wemmerlov U, Johnson DJ (1997) Cellular manufacturing at 46 user plants: implementation experiences and performance improvements. Int J Prod Res 35(1):29-49

3. Mitrofanov S (1959) Scientific principles of group technology. National Lending Library of Science and Technology, Boston

4. Jackson D (1978) Cell system of production: an effective organization structure. Business Books, London

5. Pullen RD (1976) A survey of cellular manufacturing cells. The product Engineer 56:451-454

6. Houtzeel A, Brown CS (1984) A management overview of group technology. Society of Manufacturing Engineers, Detroit, pp 3-16

7. Kusiak A, Chow WS (1988) Decomposition of manufacturing systems. IEEE J Robot Automat 4(5):457-471

8. Irani SA (1999) Handbook of cellular manufacturing systems. wiley, Hoboken

9. Agarwal A, Sarkis J (1998) A review and analysis of comparative performance studies on functional and cellular manufacturing layouts. Comput Ind Eng 34(1):77-89

10. Greene T, Sadowski R (1984) A review of cellular manufacturing assumptions, advantages, and design techniques. J Oper Manag 4(2):85-97

11. Kusiak A (1992) Intelligent manufacturing systems. Prentice Hall, Englewood

12. Joines J, Culbreth C, King R (1996) A comprehensive review of production oriented cell formation techniques. Int J Fact Automat Inf Manag 3(3-4):225-265

13. Kamrani A, Parsaie H, Chaudhry M (1993) A survey of design methods for manufacturing cells. Comput Ind Eng 25(1-4):487-490

14. Mansouri SA, Husseini SMM, Newman ST (2000) A review of the modern approaches to multi-criteria cell design. Int J Prod Res 38(5):1201-1218

15. Offodile O, Mehrez A, Grznar J (1993) Cellular manufacturing: a tax on omic review framework. J Manuf Syst 13(3):196-220

16. Kusiak A (1987) The generalized group technology concept. Int J Prod Res 25(3):561-569 
17. Ham I, Reed W (1977) First group technology survey. Machine and tool blue book

18. Hyer N (1984) The potential of group technology for U.S. manufacturing. J Oper Manag 4(3):183-202

19. Levulis R (1978) Group technology 1978: the state of Art. K. W. Tunnel, Chicago

20. Magjuka R, Schmenner R (1992) Cellular manufacturing and plant administration: some initial evidence. Labor stud J 17:44-63

21. Burbridge $\mathbf{J}$ (1979) Group technology in the engineering industry. Mechanical Engineering Publication, London, p 282

22. Dale B (1978) Just how beneficial is group technology? Mach Prod Eng 132:29-32

23. Willey PC, Dale B (1977) Manufacturing characteristics and management performance of companies under group technology. In: Proceedings of the 18th International machine tool design research conference, $777-792$

24. Harvey N (1993) The socio-technical implementation of cellular manufacturing in american and german metal working firms. $\mathrm{PhD}$ Dissertation, University of Wisconsin Madison, USA

25. Olorumnniwo FO (1997) A framework for measuring success of cellular manufacturing implementation. Int $\mathbf{J}$ Prod Res 35(11):3043-3061

26. Chandra P, Sastry T (1998) Competitiveness of Indian manufacturing: findings of the 1997 manufacturing futures survey. Vikalpa 23(3):25-36

27. Farooquie J, Mohapatra A (2007) Japanese techniques and Indian manufacturing: some inferences. In: 2007 IEEE International Conference on Industrial Engineering and Engineering Management. doi:10.1109/IEEM.2007.4419222

28. Natesan A, Loganathan K, Sambandam M (2011) A method of identifying suitable manufacturing system (cellular) for automotive sector using analytical hierarchy process. J Ind Syst Eng $5(1): 20-34$

29. do Silvio CS, Marta CM, Fabio AF (2013) A practical methodology for cellular manufacturing systems design an industrial study. Trans Control Mech Syst 2(4):198-211

30. Askin R, Selim H, Vakharia A (2013) Contributions to the design and analysis of cellular manufacturing systems. Int J Prod Res. doi:10.1080/00207543.2013.825745

31. https://docs.google.com/spreadsheet/viewform?formkey=dHp1Rk1 CLUFEUDdyNmExbXJrNOhueEE6MQ

32. Nagabhushana JT, Shah Sand (1999) Manufacturing priorities and action programmes in the changing environment: an empirical study of Indian industries. Int J Oper Prod Manag 19(4):389-400

33. Gascoigne BL, Zhang JD, Weston RH (1997) A report on the UK cell control marketplace. Integr Manuf Syst 8(3):389-400

34. Noori H (1997) Implementing advanced manufacturing technology: the perspective of a newly industrialized country(Malaysia). J High Technol Manag Res 8:1-20
35. Small MH, Yasin MM (1997) Advanced manufacturing technology, implementation policy and performance. J Oper Manag 15:349-370

36. Saberi S, Yususff RM, Zulifli N et al (2010) Effective factors on advanced manufacturing technology implementation performance: a review. J Appl Sci 10(13):1229-1242

37. Mahadevan B, Venkatarmanaiah S (2003) Re-aligning research objectives in cellular manufacturing systems design: a user's perspective. Asian Journal of Operations Management: 1-23

38. Gallagher CC, Knight WA (1986) Group technology production methods in manufacture. Ellis Horwood Limited, New York

39. Meredith J (1987) The strategic advantages of the factory of future. Calif Manag Rev 29:27-41

40. Beatty C, Gordon JRM (1990) Advanced manufacturing technology: making it happen. Bus Q 54:46-53

41. Adler PS (1988) Managing flexible automation. Calif Manag Rev 30:34-57

42. Bidanda B, Ariyawongrat $\mathrm{P}, \mathrm{Needy} \mathrm{Kl}$ et al (2005) Human related issues in manufacturing cell design, implementation, and operation: a review and survey. Comput Ind Eng 48:507-523

43. Angelis J, Conti R, Cooper C et al (2004) The effects of just-intime/lean production practices on worker job stress. The 2nd world conference on production and operations management, Cancun, Mexico, pp 1-7

44. Cantamessa M, Turroni A (1997) A pragmatic approach to machine and part grouping in cellular manufacturing system design. Int J Prod Res 35:1031-1050

45. Mahadevan B (1997) Are Indian companies ready for just-intime? Int J Fact Automat Inf Manag 3:85-92

46. Horte SA, Borjesson S, Tunalv C (1991) A panel study of manufacturing strategies in Sweden. Int J Oper Prod Manag 11(3): 135-144

47. Dangayacha GS, Deshmukh SG (2003) Evidence of manufacturing strategies in Indian industry: a survey. Int J Prod Econ 83:279-298

48. Milen R, Sohal AS (1998) Planning processes for advanced manufacturing technology by large manufacturing American manufacturers: a interdependent relationship. Technovation 18:741-750

49. Ghani K, Jayabalan V (2000) Advanced manufacturing technology and planned organizational change. J High Technol Manage Res 11:1-18

50. Ghani K, Jayabalan V, Sugumar M (2002) Impact of advanced manufacturing technology on organizational structure. J High Technol Manag Res 13:157-175 